The Sustainable City XIII 469

\title{
REGENERATION OF POST-WAR HOUSING ESTATES AND THE USE OF AGENT-BASED MODELLING
}

\author{
SZYMON MIESZKOWSKI \\ Faculty of Architecture, Wrocław University of Science and Technology, Poland
}

\begin{abstract}
Large housing estates are inseparable elements of the landscape of every Central European city and, although the predicted formation of enclaves of poverty and social exclusion has not materialised, their future does not look bright. The first post-war housing estates are inevitably approaching the end of their intended life span and, unfortunately, thus far a method to extensively test and monitor these housing estates has not yet been established. Currently, attention is focused purely on analysing the technical condition of the buildings, while the most important issue, that is, their present and future residents, is ignored. Collecting the necessary data on large residential estates is the first, extremely important step towards understanding the processes taking place in European cities. Thanks to agentbased modelling, which utilises both the decision-making and the uniqueness of individuals and households, a detailed analysis of bottom-up processes that occur naturally in the local community is possible. Using one of the Polish housing estates, Popowice in Wrocław, as an example, available statistical data was systematised and simulations were carried out to predict the natural, spontaneous development of the estate. The simulations reflect the dynamics of the bottom-up processes within the local population that have a direct impact on the scale of migration, as well as the socio-demographic polarization of the local community. Intentionally, the top-down approach has not been implemented in order to allow identification and analysis of self-modifying changes. In this simulation, trends are sought only based on the autonomy of individual people. The need to make a precise diagnosis and establish guidelines for revitalization plays a key role in the management of urban space. Strengthening the desirable, and limiting the negative processes can play a crucial role in the guideline-setting process, ultimately enabling an optimal model for the revitalization of large housing estates to be created.
\end{abstract}

Keywords: agent-based model, complex systems, large housing estates, urban regeneration, sociodemographic polarization.

\section{INTRODUCTION}

Central and Eastern Europe (CEE) countries are facing the greatest challenge since the postWorld War II reconstruction, inevitably approaching a time when they will be forced to take the first steps towards a broad revitalization programme for post-war urban districts. Industrialised housing construction, which culminated in the 1970s with large housing estates built on green sites, had for almost 30 years been practically the only form of meeting the housing needs. System-related and political factors, combined with a significant population growth, in particular a sharp rise in the number of households, contributed to the very dynamic - and often very chaotic - development of cities. Almost half of the residential buildings in post-socialist countries were built between 1946 and 1980 [1] and the vast majority of those are prefab housing estates [2]. In Western Europe, the process of humanization of the large housing estates started in the 1980s, with the regeneration process continuing to date. In the CEE countries, the situation is drastically different: the housing estates have become permanent fixtures in the urban landscape and are not expected to degrade quickly [3]. Due to the prevalence of this type of development and the changing legal structure resulting from the post-1990 privatisation process, the post-war housing blocks are still popular and highly attractive to new residents [4], [5]. The forecasts predicting a time bomb or the emergence of enclaves of social exclusion have not materialised to date [6]; however, behind the solid prefab façade, a very dynamic migration process is starting, 
providing the foundations for the evolution of the European cities. The current demographic transformations contribute to an increased rate of population migration and pose a tangible threat to the delicate balance that is maintained largely due to the attachment to the place of residence and good neighbourly relations [7]. Comparative studies to date [8], [9] have confirmed the huge differentiation and disproportions between the housing estates, depending on the country, region and city, and concurrently confirm the need for each estate to be considered individually. One of the most important premises of sustainable urban regeneration is support for desirable processes and early identification of potential threats [10]. This study describes the use of the agent-based model in order to analyse the bottomup processes in the local community and presents forward-looking simulations, highlighting the natural transformation trend on the housing estate. Based on a virtual model reflecting the architectural and urban structure of the housing estate, combined with local statistical data, a prototype of the Neighbourhood Early Warning System was built, which, once parametrised, can be commonly used in the regeneration of large housing estates.

\section{ORIGINS, CURRENT STATUS AND FUTURE OF LARGE HOUSING ESTATES}

Three general scenarios presented by Temelová et al. [11] show a wide spectrum of potential development of post-war housing estates. The most pessimistic scenario concerns estates with deeply engrained social problems, which, due to negligible opportunities for external investments, are inevitably heading towards degradation. In the middle of the scale, there are housing estates at the crossroads, whose future can be determined by revitalisation programmes by reversing the process of negative changes that has already commenced. The optimistic scenario that does not require any external intervention is forecast for the housing estates with the appropriate socio-economic structure and improving living conditions.

The Popowice housing estate, on the basis of which the agent-based model was created, is located in Wrocław, the fourth largest city in Poland in terms of population. The city, with its 640,000 inhabitants, has the highest rate of economic growth in Poland [12]. The housing estate is located in the western part of the city, which has the highest concentration of postwar block developments. When analysing the statistical data [13] and the surveys carried out at the Popowice estate regarding satisfaction with the estate and its environs, quality of life [14], business activity and unemployment [15], it seems highly likely that the estate would fall under one of the more optimistic scenarios.

The process of construction of large housing estates in Wrocław commenced in the 1960s, with the first housing estate located close to the city centre, on a site destroyed during World War II. The plans were integrated with the existing street grid, with new developments being erected next to the remnants of the old city buildings. The early 1970s marked the beginning of large housing investments and the city began to expand, especially to the west, onto undeveloped land. In total, eight large housing estates were built in Wrocław; their location is shown in Fig. 1. In 1998, 154,000 inhabitants were living on large housing estates, representing $24.2 \%$ of the city's population at the time. Gradually, over the past 20 years, the number of inhabitants of the estates has been falling by approximately $1 \%$ per annum and currently stands at 125,000 , representing $19.6 \%$ of all the inhabitants of Wrocław.

It should be pointed out that the area of the eight large housing estates represents only $2.5 \%$ of the total area of the city, and thus a detailed analysis of the transformations of the closest environment for one-fifth of the city's population is justified. The oldest estates, dating back to the late 1960 s, have the highest percentage of residents over 80 years of age, almost four times higher than the average for Wrocław. 


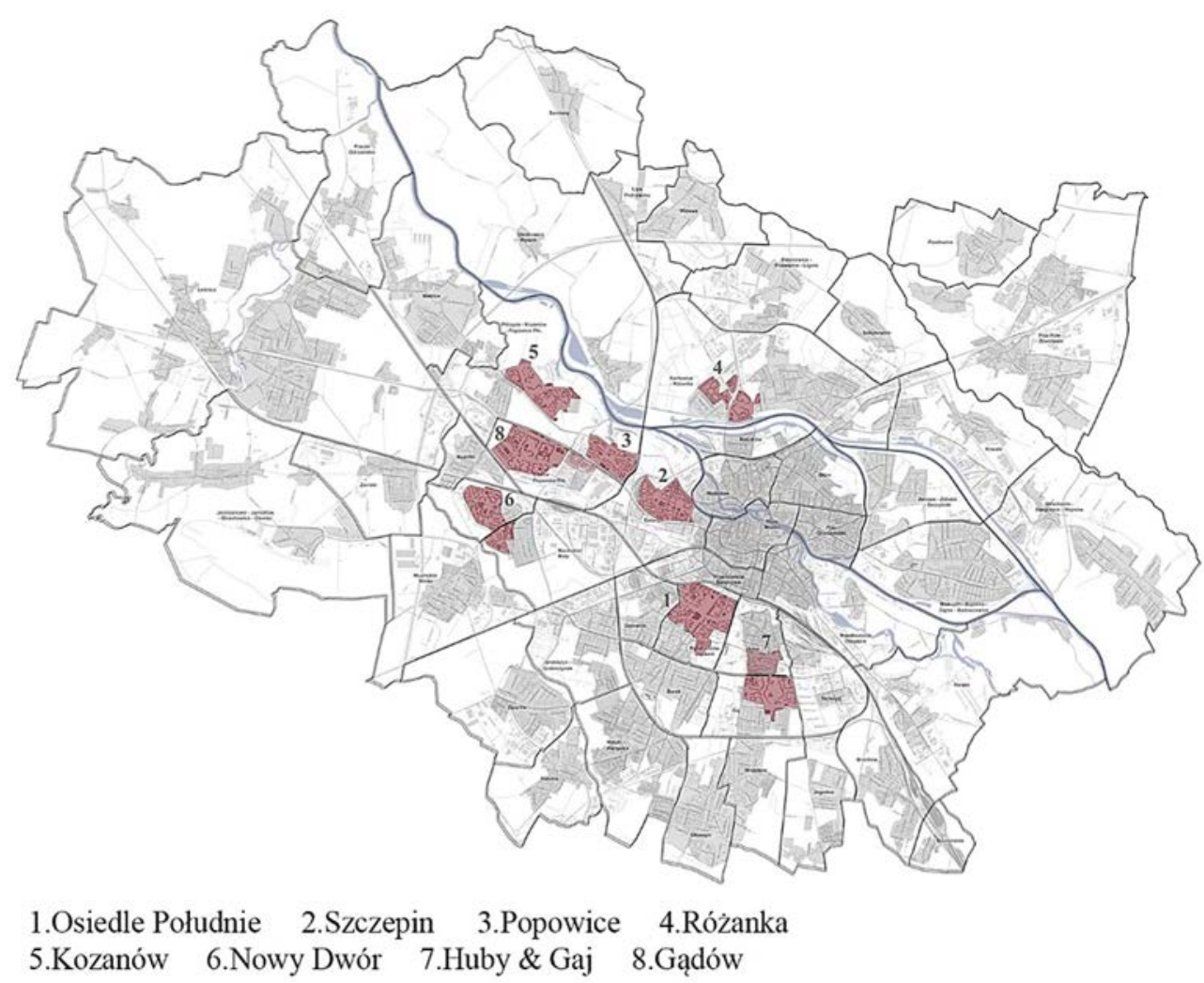

Figure 1: Location of large housing estates. (Source: Functional Analysis of Wrockaw's Housing Estates.)

The highest percentage of persons aged between 60 and 79 can be found on housing estates completed in the 1970s. The largest numbers of residents under 45 live on the newest housing estates, where construction was extended over time. The age structure of the residents, due to gradually emerging new phases, is currently very similar to the average age structure for the city. The demographics for the large housing estates and the average age structure for the city of Wrocław are shown in Fig. 2.

The research carried out to date confirms that social transformations depend on the period when the housing estate was built, and it is highly likely that the next decade will bring about key changes. The present demographic and social transformations are filter-like and are closely linked to the aging of the first-generation residents of the post-war housing estates [16]. These processes are not accompanied by lower-status residents being pushed out by new owners [17]. This is mainly due to lack of interest among private developers and local authorities in Poland, that is, the entities that are responsible for the broadly understood gentrification [18]. The widespread lack of interest amongst local municipal authorities and the transformation of first post-war housing developments may suggest that large housing estates are entering the natural generation turnaround stage and that their potential regeneration does not need to be treated as a priority. However, lack of action or delay in 


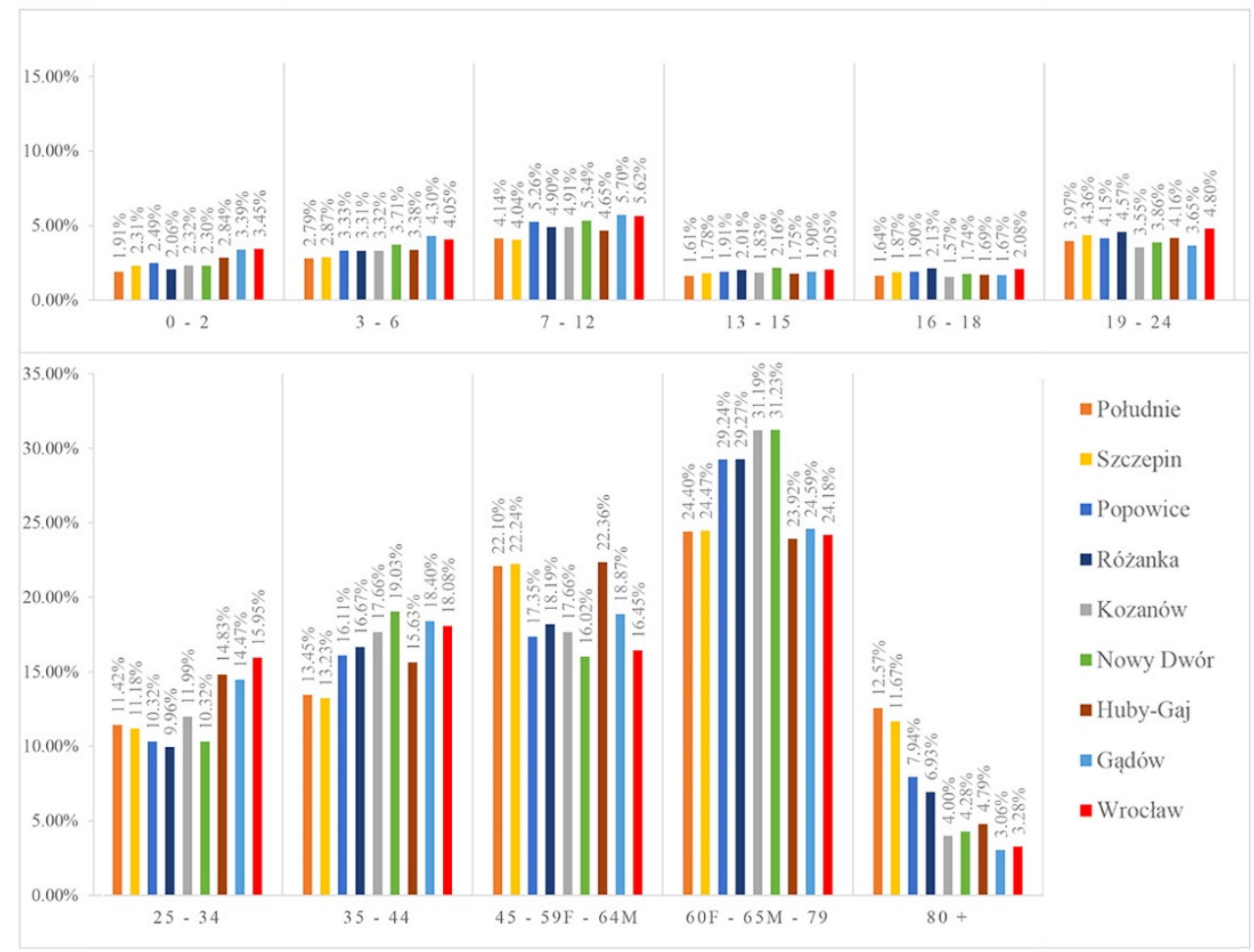

Figure 2: Age structure for large housing estates and the average age structure for the city of Wrocław. (Source: Own data, based on GUS data.)

taking appropriate administrative steps over the next few years may mean that the migration process that has already started, and in particular its scale, will bring about irreversible changes. Delayed regeneration will require much higher expenditure compared to the ongoing assistance necessary to support positive processes and mitigate undesirable changes. The analysis of the bottom-up processes occurring on large housing estates would make it possible to understand in more detail the transformations of the large housing estates and their impact on the evolution of CEE cities.

\section{AGENT-BASED MODEL OF THE ESTATE}

The agent-based model (ABM) is an ideal tool for the analysis of complex processes where the decision-making of individual agents may have an impact on the global trend [19]. Through modelling following a "bottom-up" approach, agent by agent and interaction by interaction, independent self-organisation emerges. Agents are able to interact with the environment and with other agents [20]. The main characteristic of the agents is their uniqueness and independence. Depending on the status, time and type of interaction, the agents make decisions independently, based on relatively simple rules [21]. The decision-making of individuals and the analysis of the bottom-up migration process are explored to discover key mechanisms controlling the natural evolution of the housing estate. The emphasis on modelling the heterogeneity of agents within the population and the emergence of self-organisation are two distinctive features of agent-based simulation 
compared to other simulation techniques. Individual agent modelling makes it possible to observe the effects of the diversity of individuals affecting the behaviour of the whole system, in which the emerging patterns, structures and behaviours have not been directly programmed. The main task of the model is to analyse whether it will be possible to highlight any trends that do not result from the analysis of the statistical data and surveys alone. An additional objective is to present the bottom-up processes of transformations in the local community and their dynamics. The agent-based model diagram presented in Fig. 3. shows the process of creation of agents, their parameters and development of the environment in which they will be functioning.

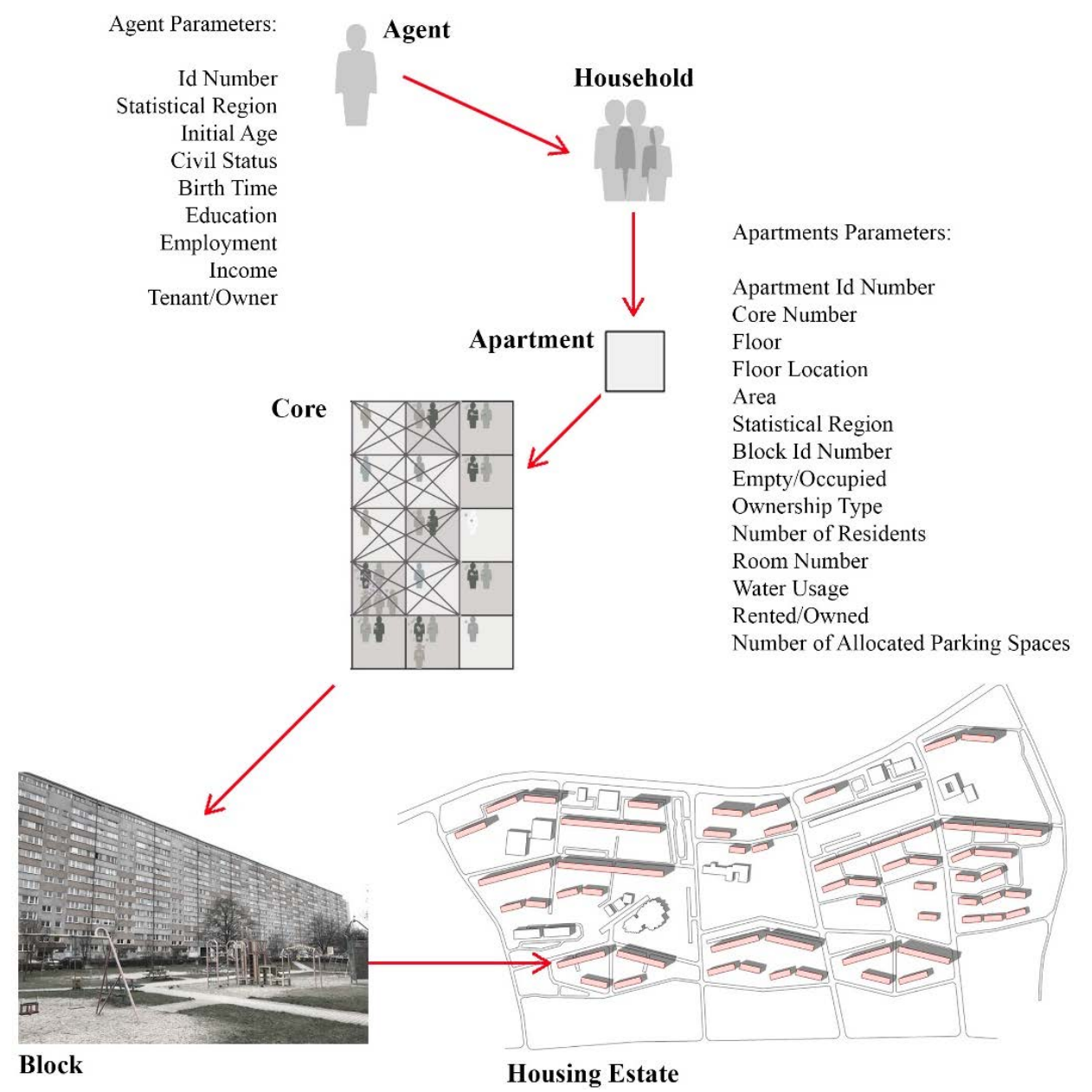

Figure 3: Model structure. (Source: Own data.)

The process of gathering information about residents was based on a multi-tier hierarchy used to search for the relevant data. Depending on availability, the necessary information was obtained in the order corresponding to its proximity to the source. First, information relating to individual statistical areas was used, followed by information about the district, city, 
region, voivodship and country. The construction of the model started with the creation of an agent population based on data from the Polish Central Statistical Office (GUS) [22], which were cross-referenced with information obtained from the Popowice Housing Association, and with annual water consumption data for each block. Each of the agents received a unique ID number, making their history trackable at any time during the simulation, and was also assigned an age parameter. Using the age-dependent femininity ratio, a parameter defining gender and marital status was assigned. Then, for each statistical area, depending on the mother's age, potential children were sought and linked to their parents, creating family households. Based on the available statistical data and market research, the characteristics of the agents were supplemented with additional parameters: education, employment status and income. The model reflects the existing composition of the estate, where each of the apartments was assigned an identification number and parameters corresponding to: statistical area, block name, stairwell number, storey and apartment's location on the floor. Additionally, parameters defining the area and the number of rooms were assigned to the apartments. The thus created apartments were combined into stairwells, making up the blocks that were subsequently plotted on the location map. At this stage, no GIS integration was introduced because changes to the local community, without any city-wide links, were in the centre of interest. Ultimately, it is anticipated that a model will be created for all large housing estates, which will then be combined into a collective model simulating changes for the entire city, of which the GIS environment will constitute an integral part.

The created population of agents, combined with the structure encompassing the apartments, family links and neighbourhood relations, forms the first level of the virtual housing estate model. At a lower level, in the agent environment, methods managing future status changes and functions controlling the agent parameters were created. They are responsible for monitoring, updating and controlling the parameters for individual agents, enabling decisions to be made autonomously. Fig. 4 shows the impact of the status on the change of each agent's parameters and the decision-making process regarding relocation. All parameters and functions were set to reflect, as closely as possible, the current demographic, social and economic situation of the local community [23]. The methods set on the life cycle graph, based on gender and actual age, are used to calculate the annual probability of death of each of the agents and, using female fertility ratios and reproduction rates, to determine the probability of giving birth. The marital status graph, for males and females separately, define the annual probability of: marriage, divorce and separation. The education graph manages the allocation of the education and qualifications parameters, having a direct impact on the employment and income parameter. Additionally, income was made dependent on experience, directly linked to age (for which a six-level scale was used) and the gender pay gap.

The relocation process in the model was limited to three fundamental functions: change in marital status, birth of a child and completion of education. If the owner of the apartment got married, a $30 \%$ probability of a decision to relocate was applied, whereas tenants were assumed to make the decision to move out and were automatically removed from the model. At the time of divorce, in households without children, it was assumed that one of the agents would move out, with a 50/50 gender split as regards the person removed from the model. In households with children, due to the low percentage of fathers who are single parents, the man is subject to relocation, whereas the woman and the children remain in the model. When a child is born, the agent (mother) checks the suitability of accommodation conditions and, when the critical values of the ratio of persons to the size of apartment are exceeded, a function is triggered that checks the income level necessary to make the decision to relocate. 


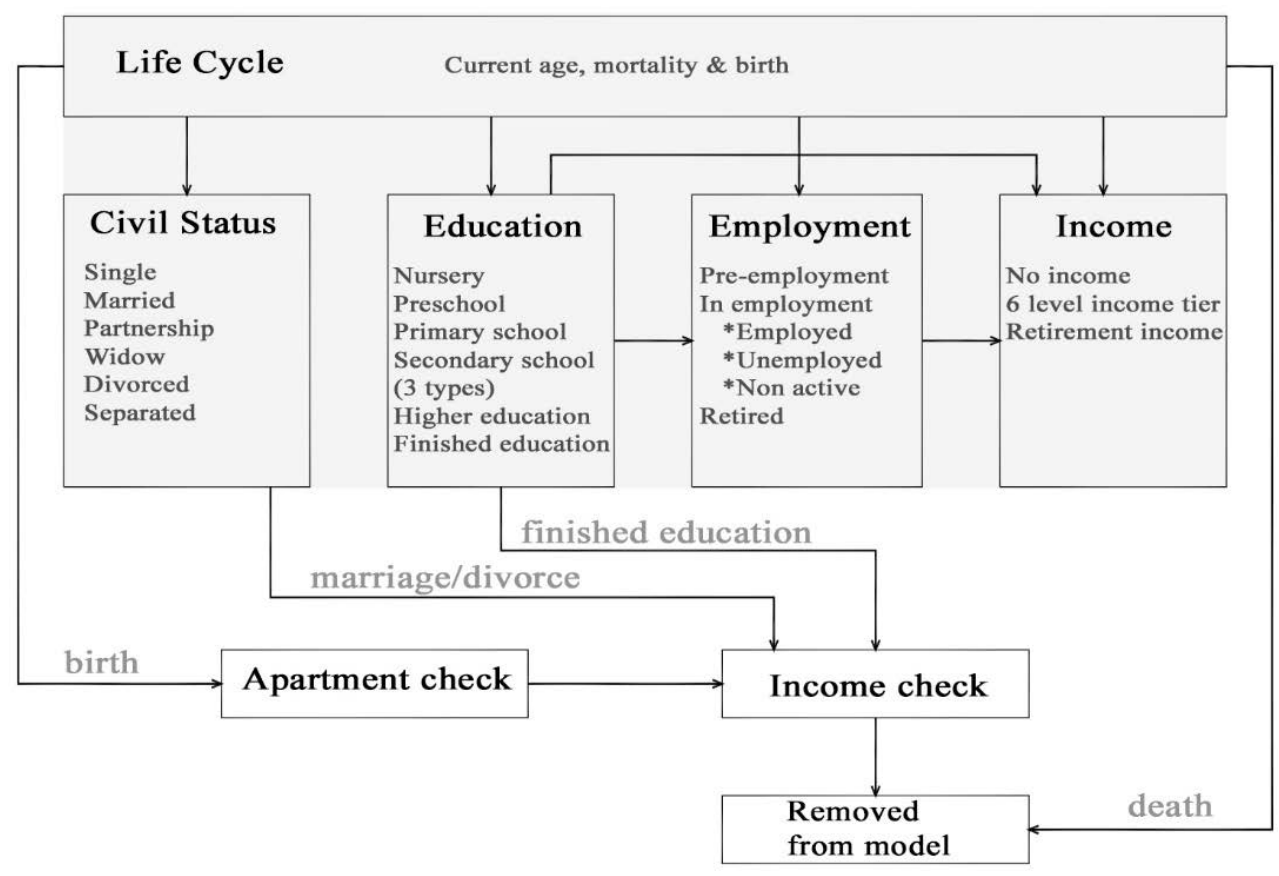

Figure 4: Managing the agents' status, parameters and relocation process. (Source: Own data.)

The analysis of the accommodation conditions at the starting point of the simulation was limited solely to households with children under the age of three. For young people who live with their parents at the time when they finish their education, a function checking their income is triggered. If that value is higher than the minimum income necessary to move out, the agent decides to relocate and is removed from the model.

The process of introducing new agents is directly linked to the dynamics of the apartments that are being vacated. Based on the research of the Wrocław housing market [24], the apartments were divided into four groups, depending on the number of rooms, and methods introducing new households were created. The main group of both tenants and buyers consists of young households, in which the head of the family is under 35 years old [25], although it should be pointed out that tenancy agreements are entered into for a relatively short term [26]. In the model, probability with triangular distribution was used, specifying the length of the lease: for people renting a room: minimum 10 months, median 12 months, maximum 24 months; for couples or families renting whole apartments: minimum 12 months, median 24 months, maximum 36 months. Due to lack of up-to-date statistical data, a $20 \%$ ratio of the total annual number of apartments purchased as rental investments was adopted, in line with the new build market.

\section{HOUSING ESTATE EVOLUTION SIMULATION}

The simulations were carried out based on the assumptions that the technical condition of the buildings will not deteriorate and the current status of the housing estate will be maintained. Stability of the property market was also assumed, where the period when a property remains up for sale depends on the size of the apartment and corresponds to the average length of the 
property sale process over the past 12 years [27]. The simulations were carried out using the AnyLogic software and cover a period of 25 years.

The information that stands out is the fact the total number of residents of the housing estate has stopped falling and has reached its target level, which will remain in the region of 10,500 over the next 25 years. However, the demographic structure of the estate has been changing dramatically; the most prominent feature is the sharp increase in the number of persons aged between 25 and 35, who in 2043 will represent as much as one-third of all residents. The number of children under 3 years of age will double, whereas the population of pre-school children will increase by $40 \%$. The middle-aged population will gradually decrease, particularly in the 35 to 45 age range, and as a result children and young people attending primary and secondary schools will practically disappear. By 2033, the number of seniors over 80 years old will increase by $50 \%$ and will represent $12 \%$ of all residents. The age structure presented in Fig. 5 in five-year periods shows the beginning of the demographic polarization process.

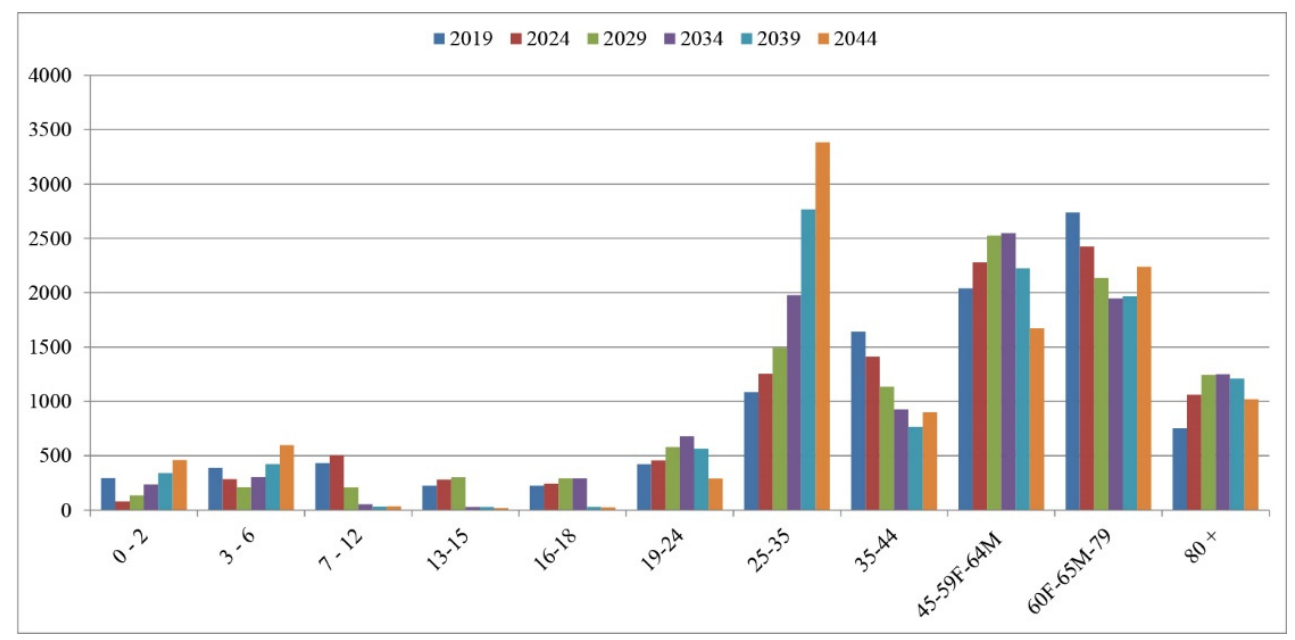

Figure 5: Age structure simulation for the Popowice housing estate, 25-year period. (Source: Own data.)

It should be noted that this does not represent the beginning of a new, natural demographic cycle. An additional simulation, analysing a further 25-year period, confirms the disappearance of the population of children, youngsters and middle-aged people. The housing estate landscape becomes dominated by young adult population, interwoven with the established senior population. Another fact giving rise to concern is the dynamically increasing rotation of residents. Each five-year period sees an almost double increase in the number of apartments appearing on the property market. These will be mostly apartments purchased a few years earlier, which no longer meet the growing households' requirements. During the first few years, resident's turnover will remain at a low level and will amount to approximately 200 persons per annum; however, it will gradually increase along with the increase in the number of vacant apartments. In 2029, the turnover of 600 people is expected, while in 2043 it might exceed 1,500. The dynamics of the internal property market on the estate, shown in Fig. 6, will mean that over a period of 25 years approximately 30,000 new residents will, for a relatively short time, be living on the Popowice estate. 


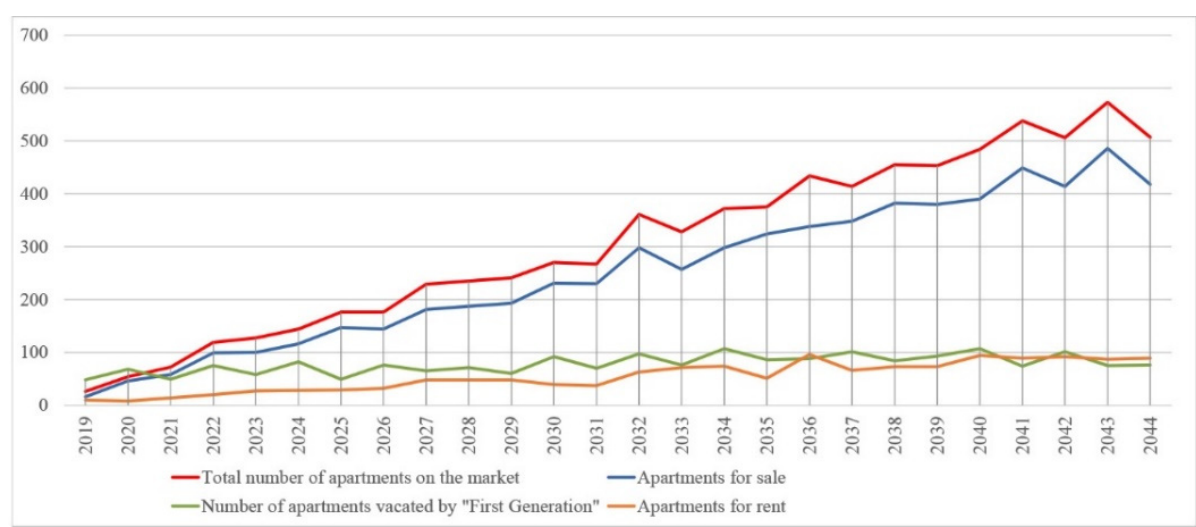

Figure 6: Simulation of vacant apartments on the property market, 25-year period. (Source: Own data.)

In the simulation, the average of 1.9 persons per apartment corresponds to the average for Wrocław; however, due to the prevalence of small apartments, the per resident area of $24 \mathrm{~m}^{2}$ differs significantly from the average for the city, amounting to $35 \mathrm{~m}^{2}$. In addition, considering that, for the next 25 years, at least one-third of the apartments will be inhabited by single occupants, mainly first-generation senior residents, the average apartment area per new resident will be $19.4 \mathrm{~m}^{2}$. It would be very difficult to consider this adequate for a dynamically developing EU city, and therefore a relatively short stay and the related increased scale of migration of the most mobile demographic group seem to be even more likely. It should be borne in mind that the results obtained from the simulation should be treated as minimum results because in reality scale and dynamic of migration can be greater. In the model, the relocation decision-making was purposefully constructed based on relatively simple and predictable principles in order to enable reliable input data to be created. The decision to move may also be impacted by the two-fold increase in the number of children under seven, exacerbating the already high demand for places in local nurseries and kindergartens. In addition, the short period of stay on the estate will make it difficult to establish desirable neighbourly relations and will make it impossible to build a strong connection and sense of belonging to the place of residence, which currently constitute the foundations for the functioning of the local community.

The oldest housing estates in Wrocław are currently entering a dynamic transformation phase, and whilst newer housing estates inevitably follow a similar path, a key element of the estate regeneration programme should be to ensure symbiotic coexistence of senior citizens with the rapidly changing younger population. Particular attention should be paid to the protection of the elderly, who are less mobile and who may find it difficult to adapt to the ongoing changes. The danger of social exclusion of a significant part of the estate community, and in particular one person households, is compounded by the maintenance costs of the apartments, which will be gradually increasing in line with the deterioration of the buildings.

\section{CONCLUSION}

A thorough, multi-level analysis, enabling the mechanisms controlling the bottom-up processes occurring in the local community to be tracked, will provide a key to a better understanding of the direction of change within large housing estates. Using the example of a housing estate built in the early 1970s, the bottom-up processes occurring in the local 
community were analysed. Using the agent-based model, simulations were carried out, presenting the most natural scenario for the natural evolution of the Popowice housing estate in Wrocław. The scale and dynamics of migration were shown, which inevitably are starting to increase for most of the housing estates. The probability of an increase in the migration trend, caused by the fluctuations in the property market cycle and increased supply of apartments, in particular in the western part of the city, and the related gradual increase in the number of apartments to rent, is very real. It seems justifiable to analyse in detail all the large housing estates in the city, and to examine their natural evolution trajectory and impact on the functioning of the city as a whole.

There is no doubt how difficult the regeneration process of entire districts will be from the legal, administrative, social and economic perspectives; however, the first step is a clear recognition of the fact that large housing estates have entered or, more appropriately, are entering a state of crisis, and any delay in identifying the exact threats may irretrievably damage their chances of a continued positive development scenario. The presented model made it possible to highlight the greatest threats to the housing estate which, if the agentbased modelling had not been used, would probably have been classified as a housing estate not requiring any external intervention, which clearly demonstrates that the agent-based modelling provides valuable additional information and should become one of the essential tools in the process aimed at formulating the regeneration guidelines. Furthermore, due to the effectiveness analysis of the tools used, ABM will make it possible to select an optimal regeneration programme and will also facilitate the monitoring of the changes occurring and potential adjustments to the project, at every stage of its implementation.

\section{REFERENCES}

[1] Nicol, S., Roys, M., Ormandy, D. \& Ezratty, V., The Cost of Poor Housing in the European Union, BRE: Watford, 2015.

[2] Dekker, K., van Kempen, R. \& Tosics, I., Large housing estates in European cities: An historical note. Utrecht University, Utrecht, 2005.

[3] Ouředníček, M., Špačková, P. \& Pospíšilová, L., Long-term development and current socio-spatial differentiation of housing estates in Prague, Czechia, Housing Estates in Europe: Poverty, Ethnic Segregation and Policy Challenges, eds D.B. Hess, T. Tammaru \& M. van Ham, pp. 339-361, Springer Open: Delf, 2018.

[4] Jarczewski, W., Rewitalizacja miast polskich - diagnoza, Skala degradacji miast w Polsce, Kraków, Instytut Rozwoju Miast, pp. 59-61, 2009.

[5] Musterd, S. \& van Kempen, R., Large-scale housing estates in European Cities: Opinions of residents on recent developments. Utrecht University, Utrecht, 2005.

[6] Enyedi, G., Transformation in Central European post-communist cities. Discussion Papers, vol. 21, Centre for Regional Studies of the Hungarian Academy of Sciences, Pécs, 1998.

[7] Szafrańska, E., Large housing estates in post-socialist Poland as a housing policy challenge. European Spatial Research and Policy, 20, pp. 119-129, 2013.

[8] Kovacs, Z. \& Herfert, G., Development pathways of large housing estates in postsocialist cities: An international comparison. Housing Studies, 27(3), pp. 324-342, 2012. DOI: 10.1080/02673037.2012.651105.

[9] Hess, D.B., Tammaru, T. \& van Ham, M. (eds), Housing Estates in Europe: Poverty, Ethnic Segregation and Policy Challenges, Springer Open: Delf, 2018.

[10] Chapple, K. \& Zuk, M., Forewarned: The use of neighbourhood early warning systems for gentrification and displacement. Cityscape, 18(3), pp. 109-130, 2016. www.jstor.org/stable/26328275. Accessed on: 10 May 2019. 
[11] Temelová, J., Novák, J., Ouředníček, M. \& Puldová, P., Housing estates in the Czech Republic after socialism: Various trajectories and inner differentiation. Urban Studies, 48(9), pp. 1811-1834, 2011. DOI: 10.1177/0042098010379279.

[12] PWC, Raport o polskich metropoliach 2015, PWC: Warsaw, 2015.

[13] GUS, Struktura wiekowa wg PESEL w rejonach statystycznych dnia 31.XII.2016, GUS, Wrocław, 2017.

[14] Mironowicz, I. (ed), Analiza Funkcjonalna Osiedli Wrocławia, Wrocław, Fundacja Dom Pokoju: Wrocław, 2016.

[15] Wrocławska Rewitalizacja, Diagnoza służąca wyznaczeniu obszaru zdegradowanego i obszaru rewitalizacji we Wrocławiu. www.wroclaw.pl/rozmawia/rewitalizacja_nowa. Accessed on: 11 May 2019.

[16] Szafrańska, E., The changes in social and demographic structure of large housing estates in post-socialist Poland and their main determinants. Folia Geographica SocioOeconomica, 30, pp. 7-26. DOI: 10.18778/1508-1117.30.01.

[17] Szafrańska, E., Gentryfikacja wielkich osiedli mieszkaniowych - nowe zjawisko czy nadużycie terminologiczne? XXV Konwersatorium Wiedzy o Mieście, University of Łódź, Łódź, pp. 153-167, 2012.

[18] Jakóbczyk-Gryszkiewicz, J., Sztybel-Boberek, M. \& Wolaniuk, A., Post-socialist gentrification processes. European Spatial Research and Policy, pp. 145-166, 2017.

[19] Heppenstall, A.J., Crooks, A.T., See, L.M. \& Batty, M., Agent-Based Models of Geographical Systems, Springer: Dordrecht, 2012.

[20] Macal, C.M. \& North, M.J., Tutorial on agent-based modelling and simulation. Journal of Simulation, 4(10), pp. 151-162, 2010. DOI: 10.1057/jos.2010.3.

[21] Macy, M.W. \& Willer R., From Factors to Actors: Computational Sociology and Agent-Based Modeling, Ithaca: Cornell University, 2001.

[22] GUS, Struktura wiekowa wg PESEL w rejonach statystycznych dnia 31.XII.2016, GUS, Wrocław, 2017.

[23] Mieszkowski, S., Use of agent-based modelling as a tool for determining guidelines in the process of revitalization of large housing estates, The Landscape Architecture Quarterly, to be published.

[24] REAS, Wrocławski Rynek Mieszkaniowy: Preferencje Nabywców Mieszkań. www.reas.pl/publikacje. Accessed on: 14 Jan. 2019.

[25] NBP, Zasobność gospodarstw domowych w Polsce. Raport z badania pilotażowego, Departament Stabilności Finansowej: Warsaw, 2015.

[26] Milewska-Wilk, H., Sytuacja najemców na rynku najmu mieszkań, Stowarzyszenie Mieszkanicznik. http://mieszkanicznik.org.pl/media/2016/09/SytuacjaNajemc\%C3\% B3wMieszkanicznik.pdf. Accessed on: 26 Nov. 2018.

[27] NBP, Sytuacja na lokalnych rynkach nieruchomości mieszkaniowych w Polsce w, 2017.

www.nbp.pl/publikacje/rynek_nieruchomosci/raport_2017_miasta.pdf. Accessed on: 26 Nov. 2018. 